\title{
Students' Attitudes Towards Implementation of Hawgent Dynamic Mathematics Software on Curved Surface
}

\author{
Yongxing Huang ${ }^{1}$, Jianlan Tang ${ }^{2}$, Jerito Pereira ${ }^{3 *}$, Chen Jihe ${ }^{4}$ \\ Maximus Tamur ${ }^{5}$, Hermita Neni ${ }^{6}$ \\ 1,2,3,4 Department Mathematics and Statistics, Guangxi Normal University, China \\ ${ }^{5}$ Pendidikan Matematika, Universitas Katolik Indonesia Santu Paulus Ruteng, Indonesia \\ ${ }^{6}$ Pendidikan Guru Sekolah Dasar, Universitas Riau, Indonesia \\ *tjlwxt@mailbox.gxnu.edu.cn
}

\begin{abstract}
Abstrak
Seiring perkembangan dunia ilmu pengetahuan semakin cepat dalam konteks pemanfaatan TIK di dunia pendidikan. Tujuan yang ingin dicapai dalam penelitian ini untuk mengetahui bagaimana respon siswa terhadap pemanfaatan aplikasi Hawgent dynamic mathematics pada materi bangun ruang sisi lengkung pada proses belajar mengajar berlansung di ruang kelas. Obyek utama pada penelitian ini adalah siswa sekolah menengah pertama kelas 9 yang sejumlah 96 siswa pada Gusui middle school in Guangxi Zhuang Autonomous Region. Pengumpulan data dalam penelitian ini berupa kuisioner yang berisikan indikator yang mengukur respon siswa terhadap penggunaan media pembelajaran menggunakan Hawgent Dynamic Mathematics dan alat utama pengolahan data penelitian yakni Ms. Excel dan SPSS statistical. Hasil penelitian terkait respon siswa bahwa siswa sejutu, senang dan terbantu dengan aplikasi Hawgent dynamic. Hasil persepsi atau respon siswa disimpulkan bahwa pada pembelajaran matematika dengan pemanfaatan software hawgent dynamic dapat membantu, memudahkan dan memuaskan siswa dalam memahami materi tentang bangun ruang sisi lengkung namun, pemanfaatan software Hawgent ini hanya terbatas pada uji coba sehingga disarankan kepada penelti selajutnya agar dapat mengunakan dan memanfaatkan software ini untuk pokok bahasan lain pada pelajaran matematika.
\end{abstract}

Kata kunci: Hawgent Dynamic, Bangun Ruang, Respon.

\begin{abstract}
Along with the development of the world of science, it is getting faster ICT in education. The objectives to be achieved in this study are to find out how the student's response to the utilization of the Hawgent Dynamic Mathematics application on the material of the curved side of the learning room in the teaching and learning process took place in the classroom. The main object in this study was the 9th-grade junior high school student who was 96 students at Gusui Middle School in Guangxi Zhuang Autonomous Region. Data collection in this study was a questionnaire containing indicators that have to measure the student's response to the use of learning media using Hawgent Dynamic Mathematics and the primary tool processing research data, namely Ms. Excel and SPSS statistical. The study results were related to the student's response that students agreed, were happy, and were assisted by the Hawgent Dynamic application. The perception or student response results concluded that learning using Hawgent Dynamic software could help in mathematics. It was easier and satisfying for students to understand the material about building a curved side space. However, the use of Hawgent software was only limited to trials, so it was recommended that it be able to use and utilize this software for other discussions on mathematics lessons.
\end{abstract}

Keywords: Hawgent Dynamic, Curved Surface, Response.

Received: Maret 29, 2021/ Accepted: Juni 28, 2021/ Published Online: Juli 29, 2021 


\section{INTRODUCTION}

In the 21st century, technology development is accelerating and technology is used in all sectors, including education sector (Widodo et al., 2021). Related to technology development in the education sector requires a professional teacher (Koh, 2019). The professional teachers must have high competence and commitment when teaching mathematics to students in schools. The professionalism of educators must maintain, enhance and expand their knowledge and skills to carry out the learning process professionally (Mizell, 2014; National Research Council, 1996). Qualified teachers are educators who are able to improve content knowledge, pedagogical knowledge and technological knowledge (TPACK). (Wati, Fitriana, \& Mardiyana, 2018); Wijaya, Ying, \& Purnama, 2020).

Previous research shows that there are still schools that do not provide adequate media or teaching aids so that teachers only rely on the blackboard to carry out teaching and learning activities. This resulted in teachers explaining the material still using conventional methods (Sheneamer, 2021). This problem must be taken seriously, so that in the future teaching and learning activities can integrate technology that makes it easier for teachers to explain material and increase student achievement, understanding abilities and student interest in mathematics. Curved surface studied in grade 9 middle school.Teaching curved surface material using traditional methods is not much efficient compared to using dynamic mathematics software. Furthermore, a curved surface drawn manually on a chalkboard has a large degree of mismatch. Inaccurate visualization can confuse students and think that curved surface lessons are difficult material.

Conducted a study on the abilities of male and female students on the topic of polyhedron and found that the male students had pratical ability better than the female students. Wati, Fitriana, \& Mardiyana, 2018). See student difficulties when learning the polyhedron concept and begin to develop learning media using Geoenzo on polyhedron material. Based on the previous research result, it can be concluded that students need mathematical software to study polyhedron and geometry material.

One of the software that can help students visualize polyhedron is Hawgent. Hawgent dynamic mathematical software has the advantage of visualizing or demonstrating mathematical concepts and as a tool for constructing mathematical concepts ( Pereira, Wijaya, \& Purnama, 2021; Pereira, Tan, Li, \& Purnama, 2020). Hawgent is a technology-based application that has often been used as a learning medium and is also used to carry out various experiments, especially in mathematics (Pereira, Wijaya, \& Purnama, 2021). Based on previous 
research studies, this software has made a significant contribution in primary school mathematics education to the university level. Hawgent software is used as a learning medium to assist teachers in explaining mathematics lessons at school. Some of these studies are the development of Hawgent dynamic mathematics software at the high school level, the subject of quadratic functions and trigonometry, arithmetic operations (Wijaya et al., 2020), In middle school, discussed the material of triangles in middle schools using Hawgent dynamic mathematics software (Xiuyan, 2018), learning media in proving the area of a kite formula and also helping to understand the concept of absolute value (Pereira, Huang, Chen, Hermita, \& Tamur, 2020; Pereira, Huang, Chen, Hermita, \& Tamur, 2020).

From some of the results of previous research, it can be concluded that Hawgent dynamic mathematics software can help students understand the material and help teachers explain mathematics material in schools. So that Hawgent dynamic mathematics software (Figure 1) can be used as an effective learning medium for visualizing mathematical objects.

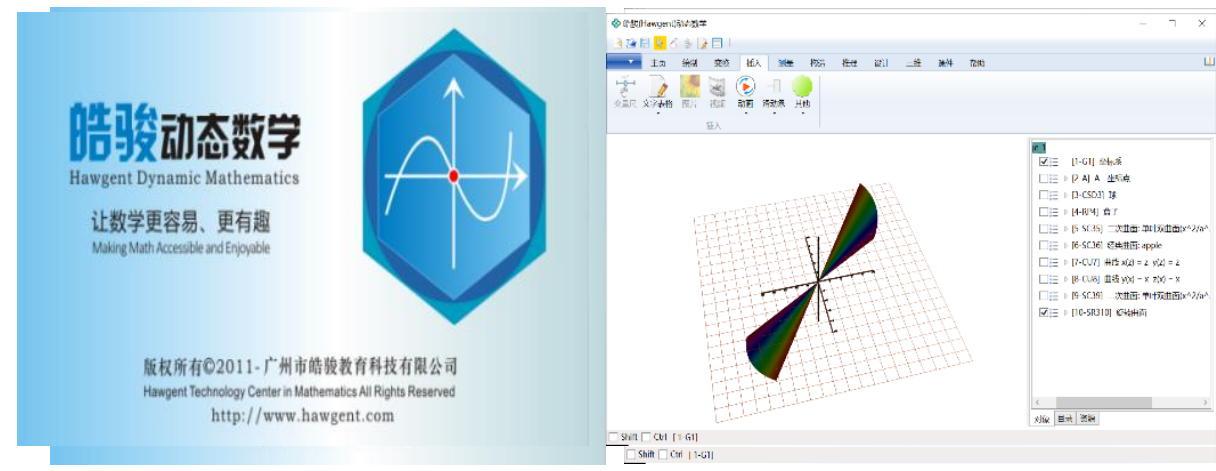

Figure 1. Hawgent dynamic mathematics software

This research is a further study of development from previous research. Many previous studies have developed learning media with Hawgent, but there is less research on students' attitudes towards using Hawgent software (Cunhua,Ying, Qunzhuang, \& Wijaya, 2019; Wijaya \& Tang, 2020). Based on this background, this research focuses on analyzing how middle school students respond to the application of Hawgent Dynamic Mathematics on the curved surface material.

\section{METHOD}

This research uses quantitative methods. The deductive approach emphasizes detailed planning for data collection and analysis (Brown, 2017; Ramos \& Carvalho, 2008). This research was conducted at one of the Gusui middle school in Guangxi Zhuang Autonomous Region. This learning trial was carried out in 4 classes that were studying the curved surface 
material with 96 students. The researcher uses Hawgent dynamic mathematics software application to visualize the sides, angles and nets of surface material. The data in this study were taken using a questionnaire. The questionnaire is a research instrument that contains several statements measured using a Likert scale with each scale having a different score (Subedi, 2016). Data processing in this study using Ms. Excel and SPSS statistical. Indicators of students' attitude towards the implementation of Hawgent dynamic mathematics software can be seen in Table 1.

Table 1. Questionnaire indicators.

\begin{tabular}{clc}
\hline No. & \multicolumn{1}{c}{ Aspect } & Indicators \\
\hline 1 & $\begin{array}{l}\text { Teaching and Learning } \\
\text { Activities }\end{array}$ & $\begin{array}{c}\text { Felling happy } \\
\text { Be motivated } \\
\text { Respond }\end{array}$ \\
\hline 2 & Understanding ability & $\begin{array}{c}\text { Helping students in learning and } \\
\text { understanding curved surface }\end{array}$ \\
\hline 3 & Hawgent dymanic & Display Easy to use \\
& mathematics software & \\
\hline
\end{tabular}

Some of the indicators above were developed into 14 statement items and some of these statements were measured using a Likert scale (Table 2).

Table 2. Likert scale

\begin{tabular}{clcc}
\hline No. & \multicolumn{1}{c}{ Category } & Code & Score \\
\hline 1 & Strongly disagree & SD & 5 \\
\hline 2 & Disagree & S & 4 \\
\hline 3 & Neither agree nor disagree & NA & 3 \\
\hline 4 & Agree & A & 2 \\
\hline 5 & Strongly agree & SA & 1 \\
\hline
\end{tabular}

This research was conducted in three stages. the stages of preparation, implementation and data collection. Researchers in the preparation stage make preparations related to material and applications. Each material about sides, angles and nets prepared by using Hawgent dynamic mathematics software application is in according with the learning objectives expected by the researchers. The implementation stage, the implementation of this research was carried out in four different classes at one of the Gusui Middle School in Guangxi Zhuang Autonomous Region. Teaching and learning activities are carried out according to the lesson plan using the Hawgent dynamic mathematics software application. In the data collection stage, data 
collection was carried out with a questionnaire that was filled in by students after the teaching and learning activities were completed. After getting the data, the researchers conducted a study of the results obtained and made conclusions.

\section{RESULT}

\section{Observation Stage}

\section{a) Curved surface material}

The material in this research is 1- curved surface. On the subject of 1-curved surface, there are three sub-topics, namely tubes, cones and balls, but in this study only discuss 2 subtopics such as tubes and cones because these two sub-topics have been studied. In each subtopic, we will study sides, angles and webs of tubes and cones. For more details, see Table 3 below.

Table 3. Implementation of the use of Hawgent in Curved Surface

\section{Sides, corners, suerface area of a tube}

1. Sides, corners, and surface area

Figure 2 is a tube has a congruent circular top and bottom side (the same shape and size). Line $\mathrm{AB}$ is the diameter of the tube base. The PE, PA, and PB lines are the radii of the tube base. The $\mathrm{BC}$ and $\mathrm{AD}$ lines are the height of the tube. The area covering the top (cover), bottom side (base) and the tube blanket is called the surface of a tube.

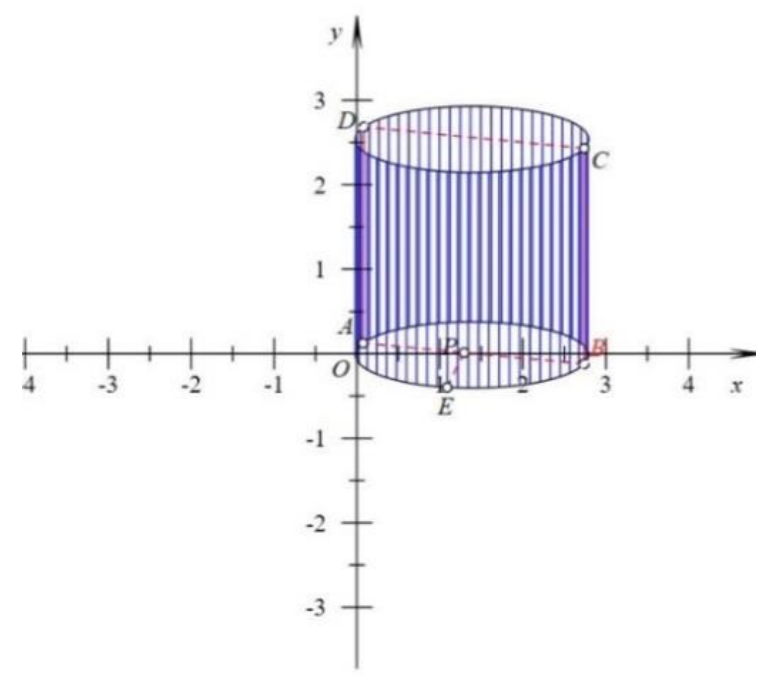

Figure 2. Sides, Corners, and Tube Covers

\section{Tube surface area}

Figure 3 is a tube having radius $r$ and height $t$. When the tube is sliced along the height line (along $\mathrm{AD}$ or $\mathrm{BC}$ ) and the curved edges (along the circumference of the 
base circle and / or along the circumference of the cap), the two circles are referred to as the base and the cap of the tube and the rectangle that covers it is called the tube blanket. A tube nets as shown in Figure 3.

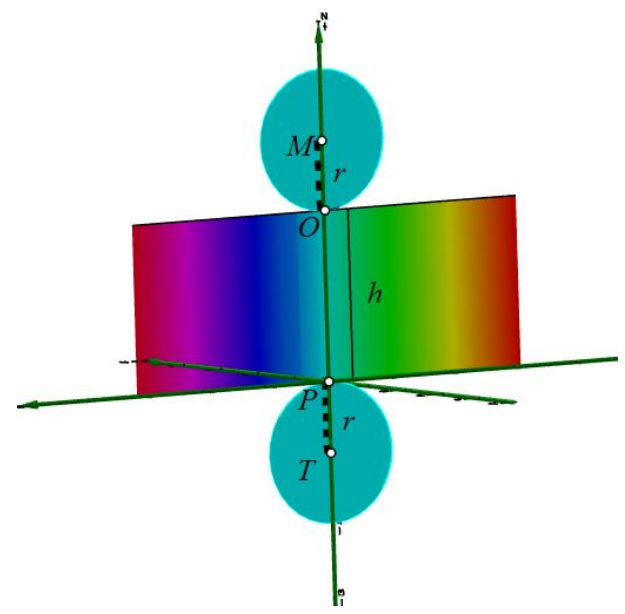

Figure 3. Tube Surface Area

\section{Cone surface area}

1 The cone section

Let us look at the shape of the cone as shown in Figure 4. The cone consists of a curved surface called the conical blanket surface and the bottom side (base) a circle. The PA and PC lines are called the radius of the cone base, the BP lines are called the height of the cone, the BA, BC lines are called the cone painter lines. A painter's line is a line that connects the top of the cone with a point on the perimeter of the base.

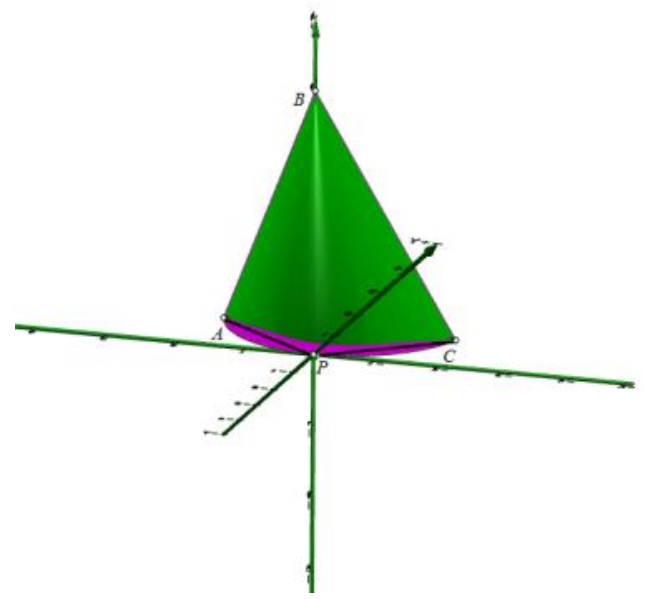

Figure 4. The cone section

Now, you can definitely distinguish between the tube and the cone. The tube does not have an angle point, while the cone has an angle point. However, tube and cones have curved edges.

2 Cone surface area

Figure 5 is a cone which has a base radius $r$ and a painter's line length $s$. If the cone as in Figure 4 is sliced along the line of the painter $\mathrm{s}$ and along the curved edge of 
the base (along the circumference of the base circle), the cone nets are obtained as shown in Figure 5.

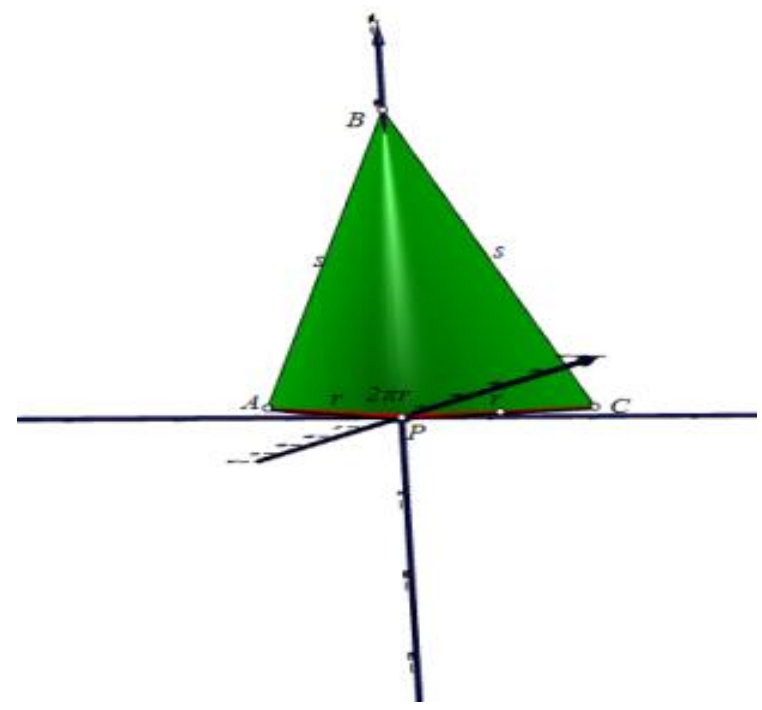

Figure 5. Cone Surface Area

\section{Design Stage}

At this stage, teaching and learning activities are carried out using the expository method. The teacher first explains the curved surface material. The expository method is a researcher explaining knowledge in an oral way and listeners who pay attention and take notes on important things. The teacher in explaining the material of curved surface discusses 1) sides, corners and tube covers and 2) sides, corners and cone blankets. The researcher describes the sides, corners and blankets of the two sub-topics using the Hawgent dynamic mathematics application.

After that, the teacher began to use Hawgent to visualize the shapes of tubes and cones in students. Visualizing the sides, corners and covers of tubes and cones with Hawgent dynamic mathematics becomes easier based on each desired function (Pereira, Tan, Li \& Purnama, 2020). For more details, see Table 4 below. 
Table 4. Learning Media Story Board

\section{Tube}

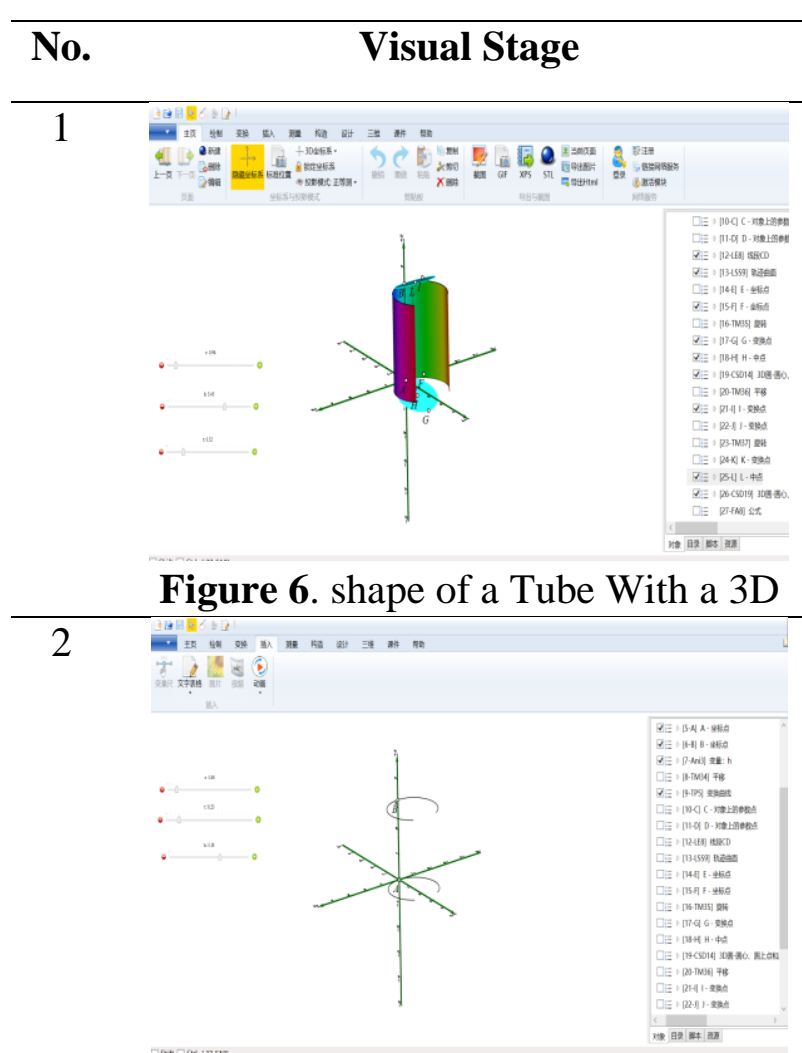

Figure 7a. 3D coordinate system

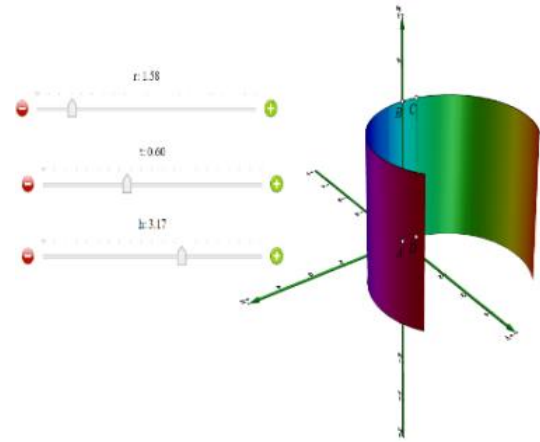

Figure 7b. The tube curved surface

3

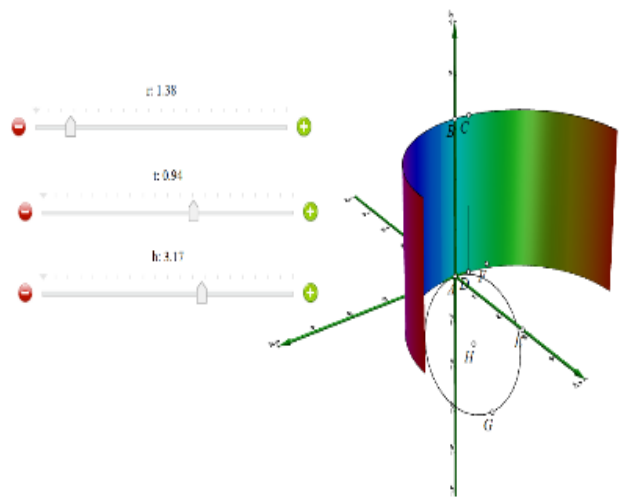

\section{Explanation}

This initial stage shows the shape of a tube space with a $3 \mathrm{D}$ coordinate system of the XYZ axis which has radius $r$, length $t$ and height $h$, sliced along the curved surface of a tube at the base, cover and along the tube height and its nets which can be seen in Figure 6.

In this first step, select the $\mathrm{XYZ}$ axis $3 \mathrm{D}$ coordinate system chart menu. Select auxiliary tools to determine tube elements such as radius $r$ and length $t$.

Next, determine the center point $\mathrm{P}$ of the $\mathrm{XYZ}$ axis $(0,0,0)$.

Make a point in the direction of the $y$ axis (point $B$ ) as the height $h$ of the tube space.

Make each point on each of the top and bottom sides.

Make a connection between the two points that are on each side.

Select the connecting line and select the track menu to form a curved surface.

provide attractive colors for students. see Figure 7a and Figure 7b .

This stage, we make the bottom side (base) and the top side (cover) a congruent circle (the same shape and size) and then both sides are given an interesting color which can be seen in Figure 8.

Figure 8. Base and Cover 


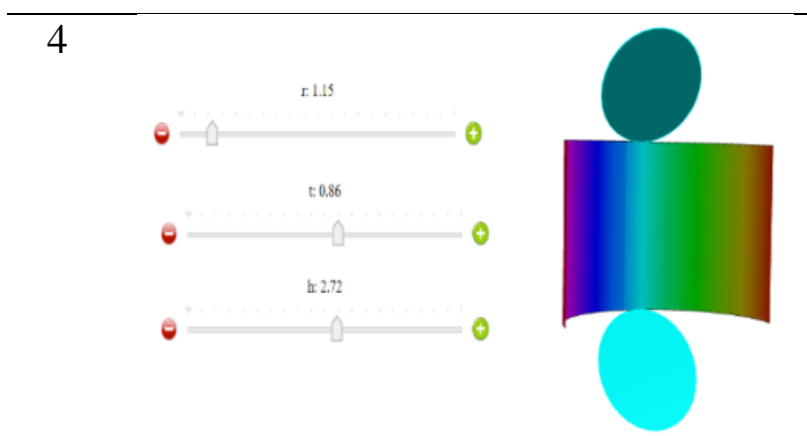

Conclusion, the surface tube consists of sides, corners and tube areas, which have a radius of $r$ and a height of $\mathrm{t} / \mathrm{h}$, which are sliced along the curved surface of the tube at the base, cover, and along the tube height which can be seen in Figure 9.

Figure 9. Sides, Corners, and Tube Covers

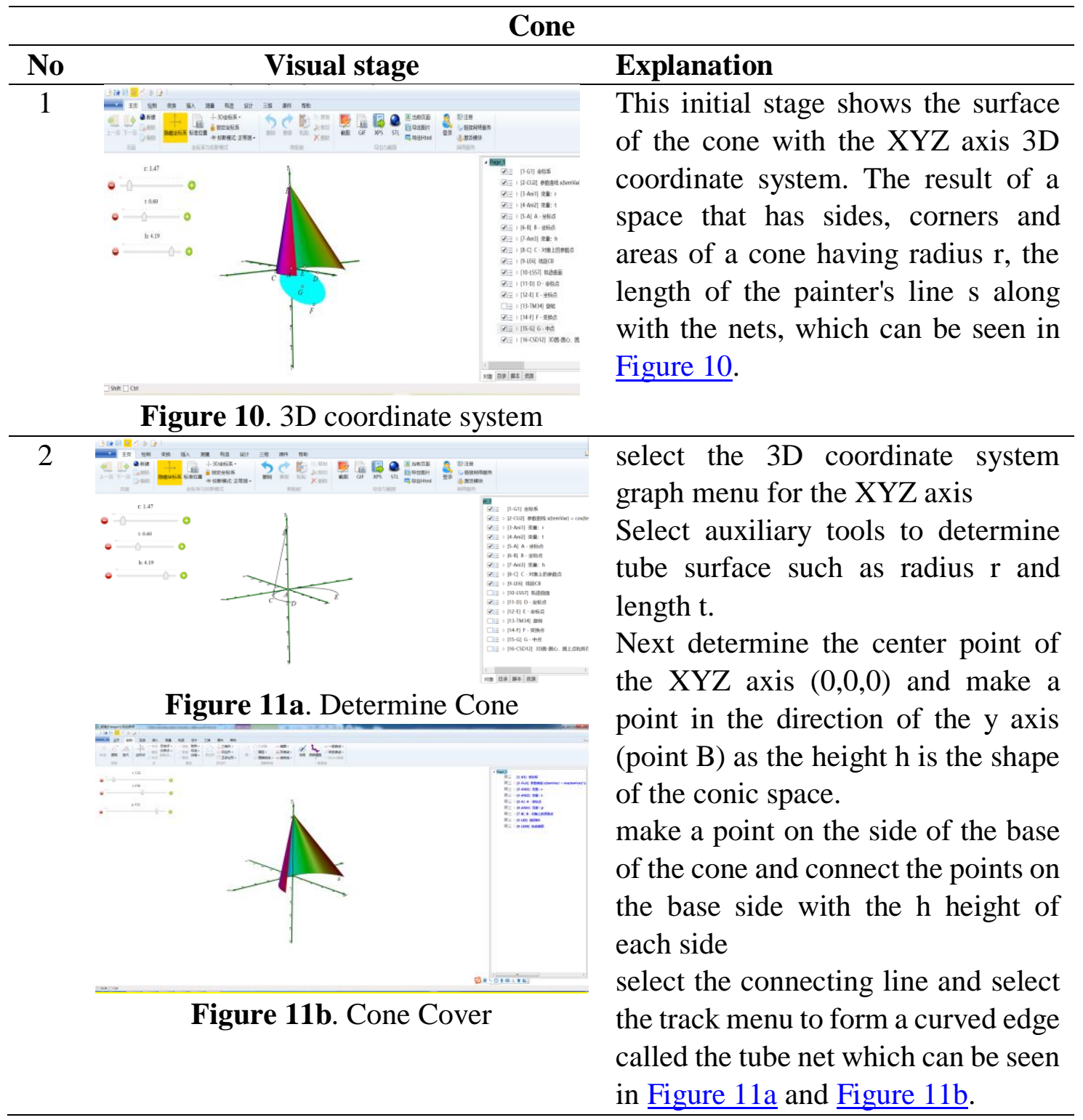




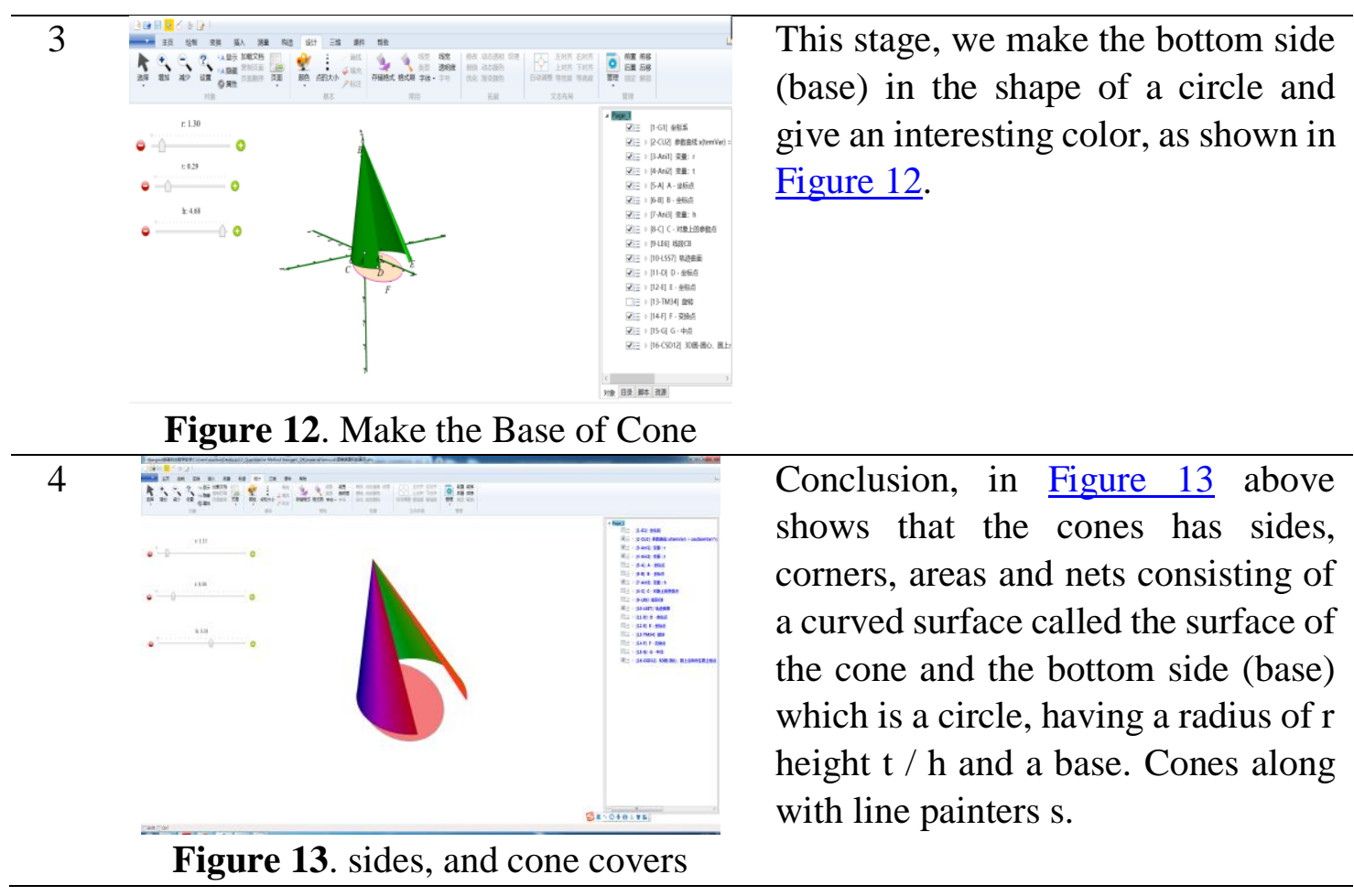

\section{Result}

The results of the students' attitude towards the implementation of Hawgent dynamic mathematics software are shown in Table 5.

Table 5. Student Responses to the Use of Hawgent Applications in Teaching and Learning Activities

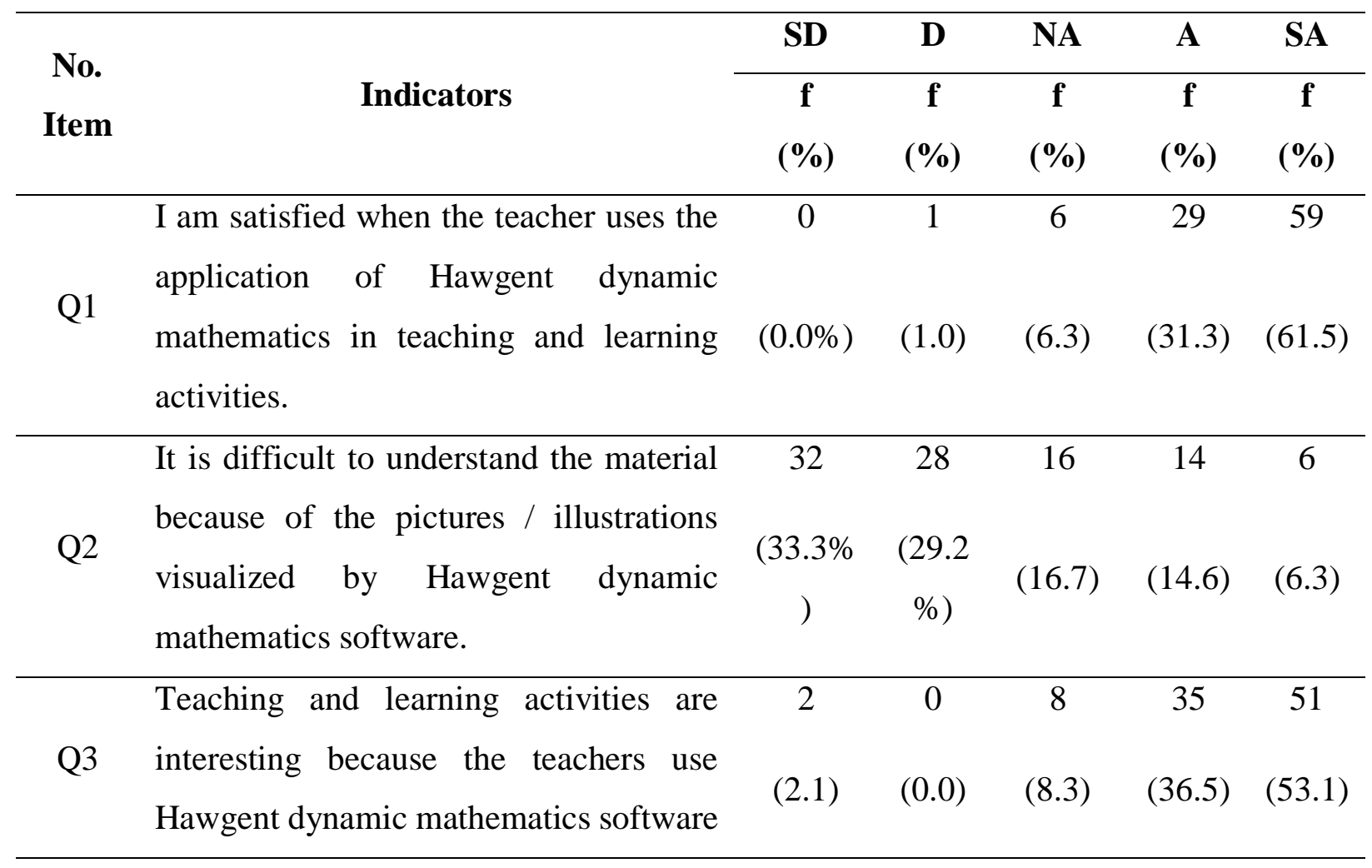




\begin{tabular}{|c|c|c|c|c|c|c|}
\hline $\begin{array}{l}\text { No. } \\
\text { Item }\end{array}$ & Indicators & $\begin{array}{c}\text { SD } \\
\text { f } \\
(\%)\end{array}$ & $\begin{array}{c}\text { D } \\
\text { f } \\
(\%)\end{array}$ & $\begin{array}{c}\text { NA } \\
\text { f } \\
(\%)\end{array}$ & $\begin{array}{c}\mathrm{A} \\
\mathbf{f} \\
(\%)\end{array}$ & $\begin{array}{c}\text { SA } \\
\text { f } \\
(\%)\end{array}$ \\
\hline Q4 & $\begin{array}{l}\text { When the process of teaching and } \\
\text { learning activities, I feel bored because } \\
\text { the teacher uses the Hawgent dynamic } \\
\text { application. }\end{array}$ & (34.4) & $\begin{array}{c}(30.2 \\
)\end{array}$ & (20.8) & (12.5) & $(2.1)$ \\
\hline Q5 & $\begin{array}{l}\text { The pictures / illustrations of Hawgent } \\
\text { are more precise and accurate than the } \\
\text { drawings made by the teacher manually. }\end{array}$ & (0.0) & (7.3) & (9.4) & (35.4) & $(47.9)$ \\
\hline Q6 & $\begin{array}{l}\text { The use of Hawgent dynamic } \\
\text { applications is easy to use in determining } \\
\text { the size of the curved surface. }\end{array}$ & (0.0) & (1.0) & (17.7) & (39.6) & (41.7) \\
\hline Q7 & $\begin{array}{l}\text { I prefer teaching and learning activities } \\
\text { using the Hawgent in curved surface. }\end{array}$ & $\begin{array}{c}1 \\
(1.0)\end{array}$ & $\begin{array}{c}0 \\
(0.0)\end{array}$ & $\begin{array}{c}12 \\
(12.5)\end{array}$ & $\begin{array}{c}34 \\
(35.4)\end{array}$ & $\begin{array}{c}49 \\
(51.0)\end{array}$ \\
\hline Q8 & $\begin{array}{l}\text { I agree with teachers who use Hawgent } \\
\text { to support and assist the teaching and } \\
\text { learning process. }\end{array}$ & $(0.0)$ & $(0.0)$ & (11.5) & (36.5) & $(52.1)$ \\
\hline Q9 & $\begin{array}{l}\text { I hope that teachers try to use the } \\
\text { Hawgent application on other math } \\
\text { subjects. }\end{array}$ & $(1.0)$ & $(1.0)$ & (11.5) & $(38.5)$ & $(50.0)$ \\
\hline Q10 & $\begin{array}{l}\text { I believe describing other polyhedrons } \\
\text { using Hawgent dynamic can make it } \\
\text { easier for students to understand. }\end{array}$ & (0.0) & (3.1) & (17.7) & (41.7) & (38.5) \\
\hline Q11 & $\begin{array}{l}\text { The use of Hawgent in the teaching and } \\
\text { learning process made me excited to ask } \\
\text { questions because some interesting } \\
\text { pictures were displayed. }\end{array}$ & (1.0) & $(0.0)$ & (13.5) & $(50.0)$ & $(35.4)$ \\
\hline Q12 & $\begin{array}{l}\text { Hawgent application is very helpful in } \\
\text { visualizing curved surface }\end{array}$ & $\begin{array}{c}0 \\
(0.0)\end{array}$ & $\begin{array}{c}1 \\
(1.0)\end{array}$ & $\begin{array}{c}15 \\
(14.6)\end{array}$ & $\begin{array}{c}47 \\
(49.0)\end{array}$ & $\begin{array}{c}33 \\
(34.4)\end{array}$ \\
\hline Q13 & $\begin{array}{l}\text { The use of Hawgent software can } \\
\text { provide 2D and 3D objects.. }\end{array}$ & $\begin{array}{c}0 \\
(0.0)\end{array}$ & $\begin{array}{c}0 \\
(0.0)\end{array}$ & $\begin{array}{c}8 \\
(8.3)\end{array}$ & $\begin{array}{c}44 \\
(45.8)\end{array}$ & $\begin{array}{c}44 \\
(45.8)\end{array}$ \\
\hline
\end{tabular}




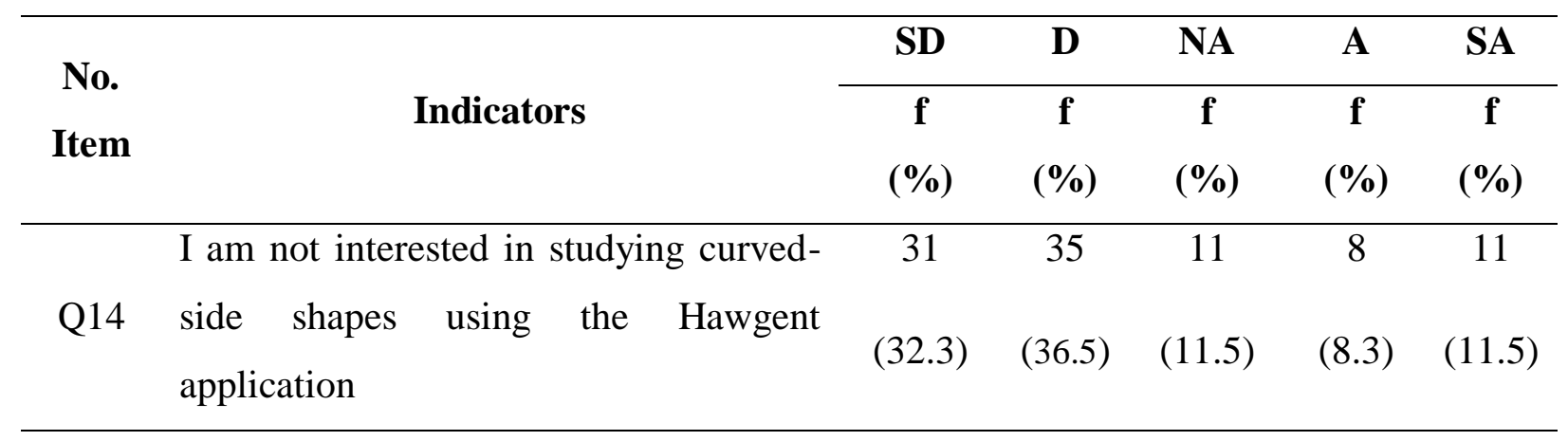

The results of the study on student responses are as in Table 3 , we get the results that students are equal, happy and their motivation to learn increases with the application of hawgent dynamic mathematics software. Of the 14 questionnaires that were used as a measure to accumulate student responses to the use of Hawgent dynamic applications so that based on the results of the calculations, the percentage of students who said strongly agree was $37.89 \%$, the percentage of students who said agree was $33.88 \%$, the percentage of students who said neither agree nor disagree $13.93 \%$, the percentage of students who said disagree was $7.80 \%$ and the percentage of students who said strongly disagree was $7.50 \%$. The results of the students' perceptions are generally seen in Graph 1.

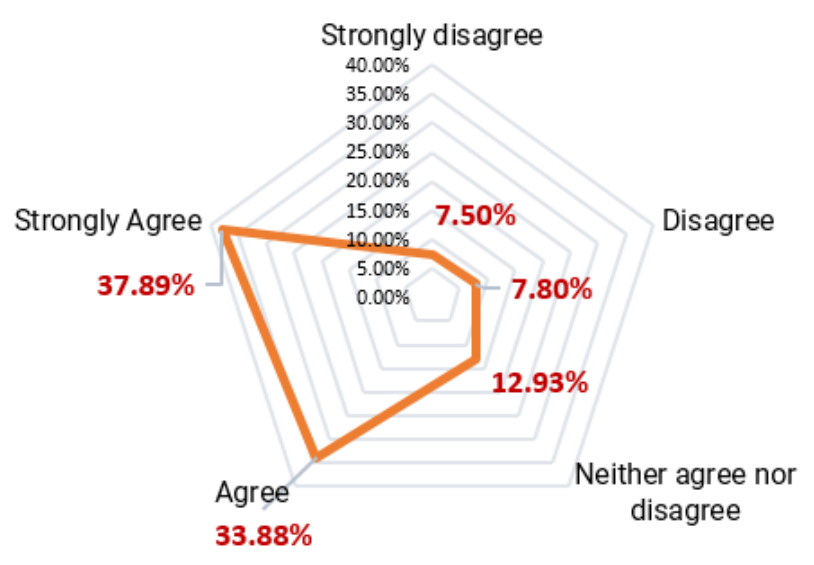

Graph 1. Recapitulation of Students' Responses

On the negative questionnaire, student responses are positive which is shown in the $2^{\text {nd }}$ questionnaire, the $4^{\text {th }}$ questionnaire and the 14 th questionnaire with each percentage can be seen in Graph 2 below. 


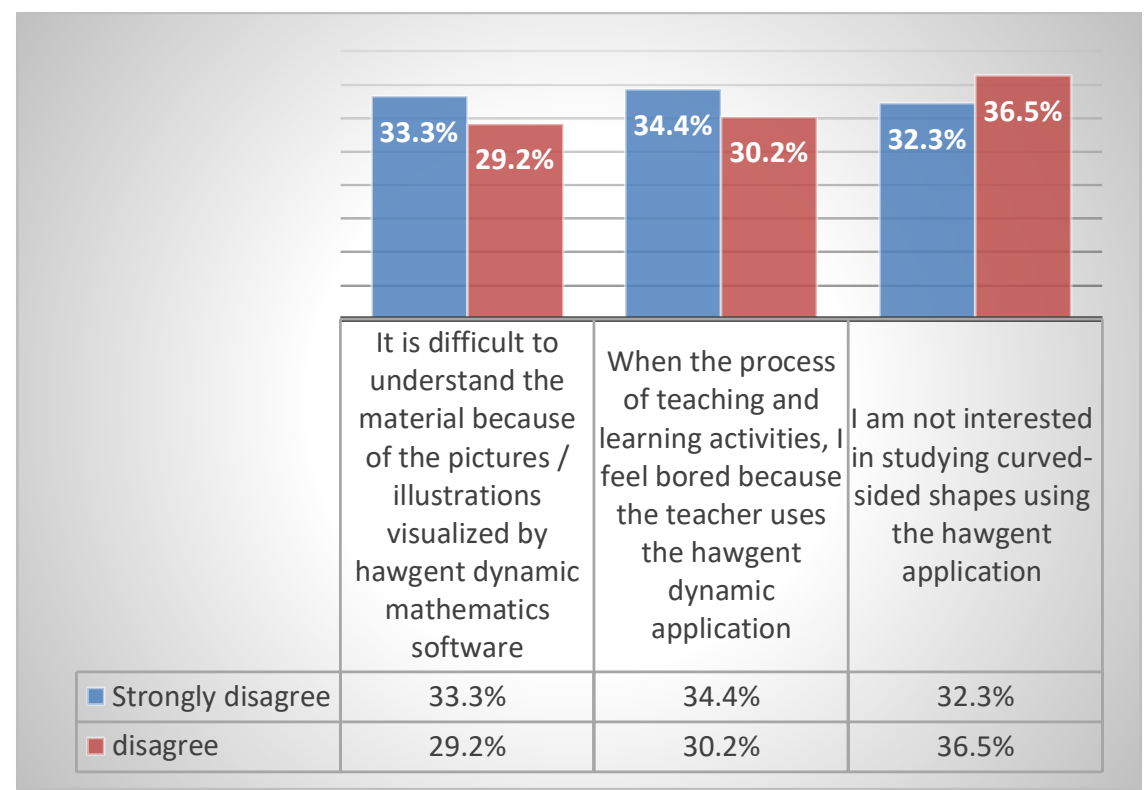

Graph 2. Student Positive Response Toward Hawgent Dynamic Software

\section{DISCUSSION}

Based on the study results, it can be concluded that Hawgent software can be used as a medium for learning mathematics because it is an ICT-based media that is very helpful for students with its very helpful features and animations. Because of the research results prove that the use of Hawgent dynamic mathematics software is very helpful in understanding mathematics material. The study results are following some of the previous research results regarding student attitudes towards using ICT-based learning media, therefore, it is suggested that mathematics teachers in particular be able to use Hawgent learning media in teaching and learning activities in the classroom.

\section{CONCLUSION}

The results of the answers to statements given by students about learning to build curved surface using the application of Hawgent dynamic mathematics can be concluded that students are equal, happy and student interest in learning increases. Of the 14 indicators that are used as a measure to accumulate student responses to the use of Hawgent dynamic applications so that based on the results of the calculation, it shows that the percentage of students with strongly agree is $38.00 \%$, the percentage of students with agree is $34.67 \%$, the percentage of students with neither agree nor disagree is $12.97 \%$, the percentage of students with a disagree of $7.35 \%$ and the percentage of students with a strongly disagree of $7.00 \%$. 
Based on the results of students 'perceptions or responses above, it is concluded that learning mathematics using Hawgent dynamic software can help, facilitate and increase students' learning interest in understanding about curved surface. Suggestions for mathematics teachers in order to take advantage of Hawgent learning media in teaching and learning activities in the classroom.

\section{REFERENCES}

Brown, G.T.L. (2017). Doctoral Education in Quantitative Research Methods : Some Thoughts about Preparing Future Scholars. Frontiers in Applied Mathematics and Statistics, 3(25), 1-12. University of Auckland. New Zealand

Cunhua, L., Ying, Z., Qunzhuang, O., \& Wijaya, T. T. (2019). Mathematics Course Design Based On Six Questions Cognitive Theory Using Hawgent Dynamic Mathematic. Journal On Education, 2(1), 36-44.

Koh, J. H. L. (2019). Articulating Teachers' Creation of Technological Pedagogical Mathematical Knowledge (TPMK) for Supporting Mathematical Inquiry with Authentic Problems. International Journal of Science and Mathematics Education, 17(6), 11951212. https://doi.org/10.1007/s10763-018-9914-y

Mizell, H. (2014). Why Professional Development Matters(Advancing Professional Learning for Student Success). Journal of Contemporary Criminal Justice, 30(4), 360-361. https://doi.org/10.1177/1043986214541602

National Research Council.(1996). National Science Education Standards. Washington, DC: The National Academies Press. https://doi.org/10.17226/4962.

Pereira, J., Wijaya, T.T., \& Purnama, A. (2021). Learning points, lines, and plane geometry withHawgent dynamic mathematics software. Journal of Physics: Conference Series. 1882 (2021), 1-7. doi:10.1088/1742-6596/1882/1/012057.

Pereira, J., Tan, S., Li, L., \& Purnama, A. (2020). Developing A Mathematics Learning Media to Explain Formula Of Area of Kite Using Hawgent. Indonesian Journal of Science and Mathematics Education, 3(3), 272-281. https://doi.org/10.24042/ijsme.v3i2.7391

Pereira, J., Huang, Y., Chen, J., Hermita, N., \& Tamur, M. (2020). Learning the Concept of Absolute Value with Hawgent Dynamic Mathematics Software. Tarbawi: Jurnal Ilmu Pendidikan, 16(2), 160-169.

Ramos, M., \& Carvalho, H. (2011). Perceptions of quantitative methods in higher education: mapping student profiles. Higher Education, 61(6), 629-647.

Sheneamer, A. (2021). Comparison of Deep Learning and Traditional Methods for Email Spam Filtering. International Journal of Advanced Computer Science and Applications, 12(1), 560-565. https://doi.org/10.14569/IJACSA.2021.0120164 
Subedi, B. P. (2016). Using Likert type data in social science research: Confusion, issues and challenges. International journal of contemporary applied sciences, 3(2), 36-49.

Widodo, A. W., Solikhatun, I., Raharja, S., Salam, A. A., \& Wartini, F. S. (2021). A Utilization of Information Technology on Education in Indonesia (2017-2020): A Systematic Literature Review. In Journal of Physics: Conference Series 1779, (1). 1-8. https://doi.org/10.1088/1742-6596/1779/1/012024

Wati, S., Fitriana, L., \& Mardiyana, (2018). Technological pedagogical content knowledge of junior high school mathematics teachers in teaching linear equation. Journal of Physics: Conference Series, 1008(1). 1-7. https://doi.org/10.1088/1742-6596/1008/1/012067

Wijaya, T. T., Ying, Z., \& Purnama, A. (2020). Using hawgent dynamic mathematic software in teaching trigonometry. International Journal of Emerging Technologies in Learning (IJET), 15(10), 215-222. https://doi.org/10.3991/ijet.v15i10.13099

Wijaya, T.T., Murni, S., Purnama, A., \& Tanuwijaya, H. (2020). Pengembangan media pembelajaran berbasis tpack menggunakan hawgent dynamic mathematics software. COLLASE (Creative of Learning Students Elementary Education), 3(3), 64-72.

Wijaya, T.T., \& Tang, J. (2020). Students ' Creativity In Designing A Mathematics Interactive Learning Media Based On TPACK Framework Using Hawgent Dynamic Mathematics Software. Emerging Technologies in Computing, Third EAI International Conference, Proceedings. 1-10. https://doi.org/10.1007/978-3-030-60036-5_24.

Xiuyan, Y. (2018). The comparison of Geometry Sketchpad, Linglong Sketchpad and Hawgent Dynamics Mathematics and its application in teaching math. Publication of dissertation. China. Guangxi Normal University. 